\title{
EDITORIAL
}

\section{A new beginning}

\section{Anirudh Kohli}

Head of Imaging Department, Breach Candy Hospital, 60 Bhulabhai Desai Road, Mumbai, Maharashtra, India.

E-mail: dranirudhkohli@gmail.com

Dear Colleagues,

Thank you very much for giving me the opportunity to serve you as "Editor-in-chief" of the Indian Journal of Radiology and Imaging (IJRI) 2019-2021.

Dr. Chander Mohan, Editor-in-chief of IJRI 2016-2018, has done a tremendous job of taking IJRI to its present high international standard. I also thank previous core editorial team for their hard work for IJRI. There has been a procedural delay at IRIA, ICRI, and IJRI in handing over the baton to the new office bearers. Dr. Chander Mohan has beyond the call of his duty brought this issue out, so that the show goes on!!. Thank you Dr. Chander Mohan. It is only just, that he penned the editorial for this issue.

Dr. Ankur Shah, a well-known academic radiologist, has kindly consented to be Joint-editor and Secretary of IJRI 2019-2021. Thank you! and welcome Dr. Ankur Shah.

Reviewers do a thankless job of reviewing articles with a strict deadline. Thank you, reviewers, for your tireless efforts. As we reconstruct the editorial review board, IJRI welcomes existing reviewers as well as fresh talent. Please send an email to IJRI regarding your desire to be a reviewer with your credentials.

The most important element of a journal is the authors who generate the content. IJRI thanks past and present authors for their contribution and IJRI looks forward to their continuing contribution, as well as encourages many more authors in the future. IJRI will hand hold new authors through their process of researching, writing, and submission to facilitate and encourage them.
As technology rapidly advances, it is extremely important to stay abreast with continuing medical education. IJRI would like to help increase your knowledge bank. Under the aegis of IJRI, based on obtaining necessary approvals, we plan to start new additional subsidiary journals: A pictorial essay journal, a symposium journal dedicated to a particular topic, thus supplementing text books. Students spend months on their thesis, which is seen only by a few. Their hard work rarely sees the time of day. With the launch of Yuva IRIA, we plan to have a journal where students can publish their thesis in 500 words. This way, everyone will be enlightened on the research undertaken by these students, as well as spur them on to perform more dedicated and meaningful research.

These are some of the new initiatives we plan, more will unfold in the months to come.

This is an open access journal, and articles are distributed under the terms of the Creative Commons Attribution-NonCommercial-ShareAlike 4.0 License, which allows others to remix, tweak, and build upon the work non-commercially, as long as appropriate credit is given and the new creations are licensed under the identical terms.

\begin{tabular}{|l|l|}
\hline \multicolumn{2}{|c|}{ Access this article online } \\
\hline Quick Response Code: & Website: \\
& www.ijri.org \\
\hline
\end{tabular}

Cite this article as: Kohli A. A new beginning. Indian J Radiol Imaging 2019;29:1. 